Boletín de la Sociedad Geológica Mexicana

VOLUMEN 67, NÚM. 1, 2015, P. 75-86

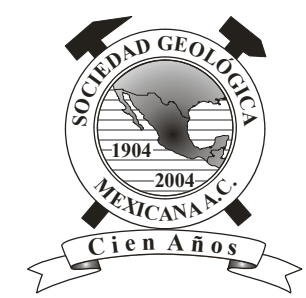

\title{
Calpionellid biostratigraphy, U-Pb geochronology and microfacies of the Upper Jurassic-Lower Cretaceous Pimienta Formation (Tamazunchale, San Luis Potosí, central-eastern Mexico)
}

\author{
Rafael López-Martínez ${ }^{1, *}$, Ricardo Barragán ${ }^{1}$, Daniela Reháková ${ }^{2}$, Michelangelo Martini ${ }^{1}$, \\ Samuel Eguiluz de Antuñano ${ }^{3}$ \\ ${ }^{1}$ Instituto de Geología, Universidad Nacional Autónoma de México, Ciudad Universitaria, Delegación Coyoacán, C.P. 04510, México \\ D.F., Mexico. \\ ${ }^{2}$ Comenius University, Faculty of Natural Sciences, Department of Geology and Paleontology, Mlynská dolina G, 84215 Bratislava, \\ Slovak Republic. \\ ${ }^{3}$ Geologist assessor, Bonampak 103, Coyoacán, C. P. 04700, México, D.F., Mexico. \\ *ralopezm@geologia.unam.mx
}

\begin{abstract}
Detailed sampling of a stratigraphic section corresponding to the La Pimienta Formation in the state of San Luis Potosí allows the determination of the upper Tithonian Crassicollaria Zone (Remanei, Brevis and Colomi Subzones). The presence of Praetintinnopsella andrusovi Borza and chitinoidellids in the Crassicollaria Zone, was interpreted as the result of sedimentary reworking as due to fact that these taxa have not been reported in such a high stratigraphic position. Nonetheless additional work is needed in order to establish a clear relationship. The U-Pb date for a bentonite bed that underlies rocks of the Elliptica Subzone is $139.1 \pm 2.6 \mathrm{Ma}$ (late Berriasian-early Valanginian). These new data suggest a different age range for the Elliptica Subzone in Mexico as compared with coeval sections in the Mediterranean Tethys.
\end{abstract}

Keywords: Calpionellids, microfacies, Upper Jurassic-Lower Cretaceous, central-eastern Mexico.

\section{Resumen}

El muestreo detallado de una sección estratigráfica de la Formación Pimienta en el estado de San Luis Potosí permitió el reconocimiento de la Zona de Crassicollaria del Tithoniano superior (Subzonas Remanie, Brevis y Colomi). La presencia de Praetintinnopsella andrusovi Borza y chitinoidélidos en facies pertenecientes a la Zona de Crassicollaria se interpreta como resultado de retrabajo pues el rango estratigráfico de estos taxones no ha sido reportado con anterioridad abarcando estas biozonas. Sin embargo se necesitan trabajos adicionales para esclarecer su verdadera relación. Análisis geocronológicos de U-Pb realizados en una capa de bentonita que subyace a la Subzona Elliptica (Zona Calpionella) indicaron edades de $139.1 \pm 2.6$ Ma correspondientes al Berriasiano tardio-Valanginiano temprano. Estos nuevos datos sugieren un rango de edad diferente para la Subzona de Elliptica en México comparado con secciones similares en el Este del Tethys.

Palabras clave: Calpionélidos, microfacies, Jurásico Superior-Cretácico Inferior, centro-este de México. 


\section{Introduction}

The study of calpionellids in Mexico and especially late Tithonian calpionellids has been controversial. Locally, Tithonian sediments mainly contain radiolarian and are associated with large amounts of siliciclastics. These special conditions produced some differences with respect to coeval facies further east in Tethys where micritic limestones favor the preservation of abundant calcareous microplankton (calpionellids, dinoflagellates and nannofossils).

Adatte et al. (1996) argued that in northern Mexico, markers or species of the Chitinoidella and Crassicollaria Zones were absent. The authors explained this phenomenon by inferring the isolation of Mexico from the rest of the Tethys and paleoclimatological conditions. Nonetheless, in central Mexico Adatte et al. (1996) reported the presence of the genus Chitinoidella and Saccocoma sp. in the Guapote and Tehepican profiles. These finds at outcrops confirmed the results from oil exploration cores (Lugo, 1975) and demonstrate the presence of Tithonian calpionellids in Mexico.

Adatte et al. (1996) concluded that the influence of the Tethys on central-eastern Mexico during the Tithonian was sporadic, with short-lived incursions and no permanent connection.

Different opinions on the topic can be found in the literature (Cantú-Chapa, 1967, 1989; Adatte et al., 1992; Stinnesbeck et al., 1993; Eguiluz et al., 2012; LópezMartínez et al., 2013). However, the controversy persists and is still far from resolution.

Furthermore, the age of calpionellid biozones in Mexico has not been determined with precision due to the scarcity of ammonites and other biostratigraphical markers in the studied sections. Thus, correlation of calpionellid biozones is still tentative. Main calpionellid bioevents have been recognized in Mexican sections and correlated approximately with coeval sections in the rest of the Tethys. Nonetheless, successions of calpionellids are not strictly identical to those defined in Europe and North Africa. Thus the question of the real span of calpionellid species and their biozones in Mexico is still under debate.

Calpionellid bioevents, U-Pb geochronology and facies in the Tamazunchale section shed new light on calpionellid distribution in central-eastern Mexico. Our results show for the first time the occurrence of Praetintinnopsella andrusovi Borza in western Tethys as well as a more complete standard Crassicollaria Zone with its subzones. Furthermore, U-Pb dates on bentonites in the Elliptica subzone allow us to present new information on the age of that biozone in western Tethys.

\section{Material and methods}

\subsection{Biostratigraphy}

Due to the poor preservation and scarcity of calpionellids in Mexican sections (Cantú-Chapa, 1989; Adatte et al., 1994; Eguiluz et al., 2012; López-Martínez et al., 2013), in this work it was necessary to use a methodology based on detailed sampling and observation of microfacies, so as to improve on previous biostratigraphical results.

Detailed bed -by- bed sampling and a grid observation of at least two thin sections (of different orientation) of beds and interbeds were carried out. Ninety-two samples were collected from thirty-two beds and thin sections were studied under LEICA DM 2500 and Olympus Bx 60 microscopes.

Generally accepted calpionellid zonations proposed from different Tethyan areas have been considered; and the standard calpionellid zones and subzones sensu Reháková and Michalík (1997) have been adopted.

\subsection{U-Pb geochronology}

In order to constrain the succession in an absolute chronostratigraphic framework, zircons separated from one felsic tuff layer were dated by laser ablation inductivelycoupled plasma mass spectrometry (LA-ICPMS) at the Isotopic Studies Laboratory of the Centro de Geociencias, UNAM. Mineral separation was carried out using the standard methodology (Morton, 1985) at the mineral separation facility of the Instituto de Geología, UNAM. Zircons were observed and imaged under cathodoluminescence (CL) using an ELM3R luminoscope connected to a digital camera. Individual zircon ages were obtained with a Thermo Neptune Plus Multi Collector-ICPMS coupled to a Resonetics Resolution M050 excimer laser workstation. Details of the analytic methodology can be found in Solari et al. (2010). Tera-Wasserburg (1972) concordia and weighted mean diagrams were obtained using Isoplot v. 3.06 (Ludwig, 2004). Plots were constructed using the ${ }^{206} \mathrm{~Pb} /{ }^{238} \mathrm{U}$ age for zircons younger than $1.0 \mathrm{Ga}$, whereas ${ }^{207} \mathrm{~Pb} /{ }^{206} \mathrm{~Pb}$ ages were preferred for grains older than $1 \mathrm{Ga}$. As a statistical rejection criterion, $30 \%$ normal and $5 \%$ reverse discordancy was chosen (Harris et al., 2004; Gehrels, 2011), and none of these zircons are included in the plots or discussion below. Details on the analytical results of the analyzed samples are given in Table 1.

\section{Geological setting}

The section studied is located in central-eastern Mexico at the border between the states of Hidalgo and San Luis Potosí near the towns of Chapulhuacán and Tamazunchale. The section is located at $21^{\circ} 10^{\prime} 3.11^{\prime \prime} \mathrm{N}$ and $98^{\circ} 54^{\prime} 49.99^{\prime \prime} \mathrm{W}$ and consists of $50 \mathrm{~m}$ of thin limestone-bentonite intercalations (Figure 1). Geologically it forms part of the Mexican FoldThrust Belt (Eguiluz et al., 2000) and is next to the western part of the Tampico-Misantla Basin.

The geological units of the aforementioned belt start with continental facies related to the opening of the Gulf 
Table 1. U-Pb geochronological results for the dated tuff sample.

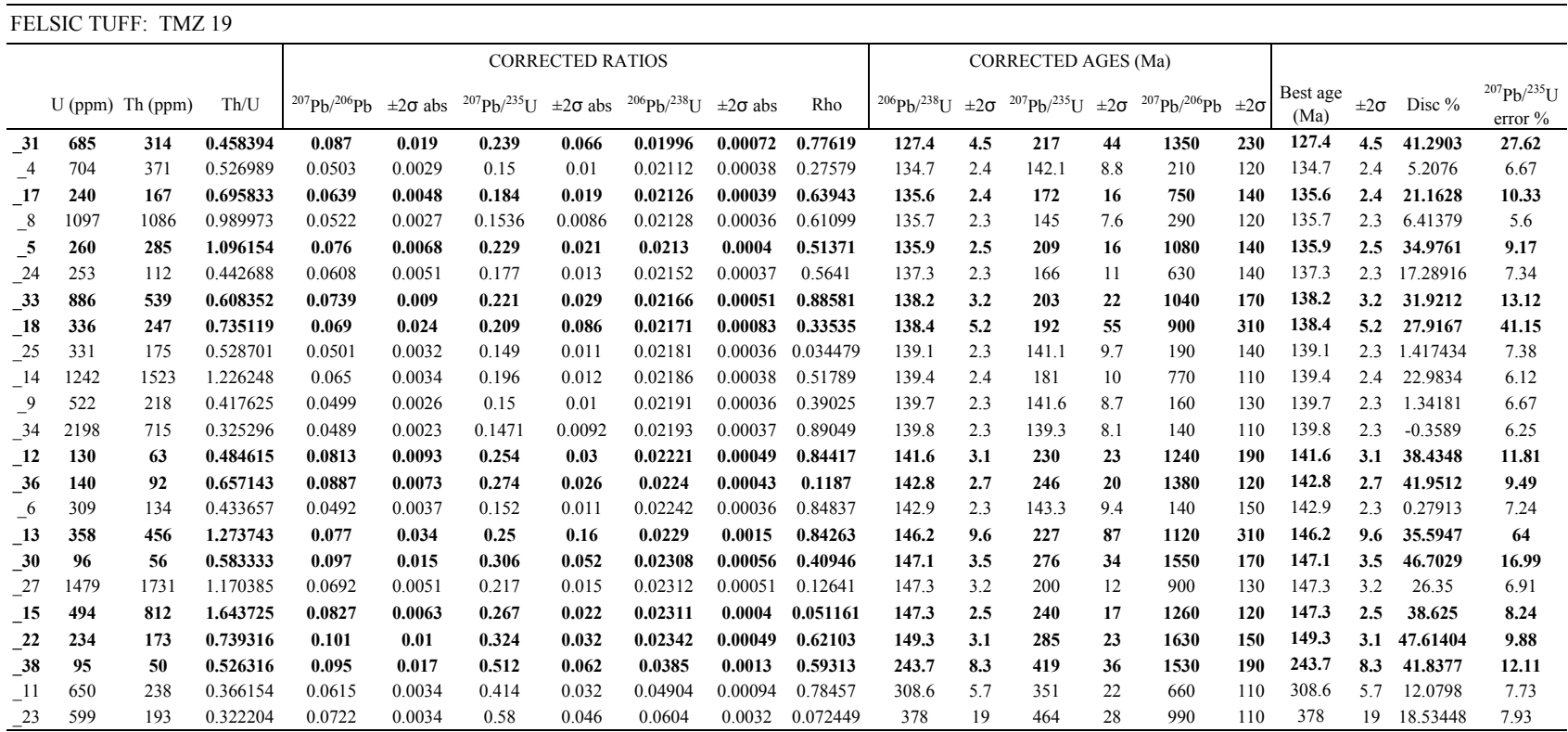

of Mexico (Salvador, 1991; Stern and Dickinson, 2010), which evolve to shallow marine facies that gradually change to a thick open marine carbonate-siliciclastic unit. The whole sequence is capped with regressive fore-deep turbiditic facies.

The present work focuses on a section in the Pimienta Formation, in the upper part of the open marine carbonatesiliclastic unit (Figure 2).

This formation was defined by Heim (1940) as "well stratified limestones with black chert intercalations". Sutter (1990) estimated its thickness at more than $300 \mathrm{~m}$. Frequent green bentonitic layers are documented in the upper part of the formation (Bondelos, 1956).

Bonet (1956) on the basis of calpionellid content and Cantú-Chapa (1971) on the base of ammonites estimated the relative age of this formation as Late Jurassic to early Berriasian.

\section{Results}

\subsection{Calpionellid Biostratigraphy}

Observed fine-grained sediments of the Tamazunchale section contain predominantly pelagic microfossils (radiolarians and calpionellids). The succession of calpionellids in the section allows us to identify calpionellid zones and subzones as follows:

\subsubsection{Crassicollaria Zone, Remanei Subzone. Samples: TMZ 2-6}

The interval is defined by the first occurrence (FO) of Tintinnopsella remanei (Borza) in microfacies dominated by Crassicollaria intermedia Durand-Delga (Reháková and Michalík, 1997). The calpionellid association in the studied section is composed of Chitinoidella cf. elongata (Pop) (Figure 3 A, B), Tintinnopsella remanei (Borza), (Figure 3 C, D), Crassicollaria sp. (Figure 3 E) and Calpionella alpina Lorenz (Figure $3 \mathrm{~F}$ ). Crassicollaria intermedia Durand-Delga was not observed.

The microfacies of this interval are characterized by wackestone-packstone of calcified radiolarians with less abundant calpionellids. Intervals with stratiform black cherts or chert nodules are frequent.

\subsubsection{Crassicollaria Zone, Brevis Subzone. Samples: TMZ 7-10}

The Brevis Subzone (sensu Reháková and Michalík, 1997) is the part of the Crassicollaria Zone that is characterized by a diverse and abundant calpionellid association. It corresponds to the Intermedia Subzone of Remane (1986) or Massutiniana Subzone of Lakova (1993). In the Tamazunchale section, the subzone is characterized by a poor calpionellid association composed of Calpionella alpina Lorenz (Figure $3 \mathrm{G}$ ), Crassicollaria sp. (Figure 3 E), Crassicollaria massutiniana Colom (Figure $3 \mathrm{H}$ ), Tintinnopsella carpathica (Murgeanu and Filipescu) (Figure $3 \mathrm{I}$ ) and Praetintinnopsella andrusovi Borza (Figure $3 \mathrm{~J}$ ). Due to the scarcity of calpionellids and the missing species normally found in the Intermedia Subzone (sensu Remane, 1986), the presence of Crassicollaria massutiniana Colom instead leads us to consider the interval to be the Brevis Subzone.

The microfacies of this interval are wackestones to packstones in which calcified radiolarians are dominant. 

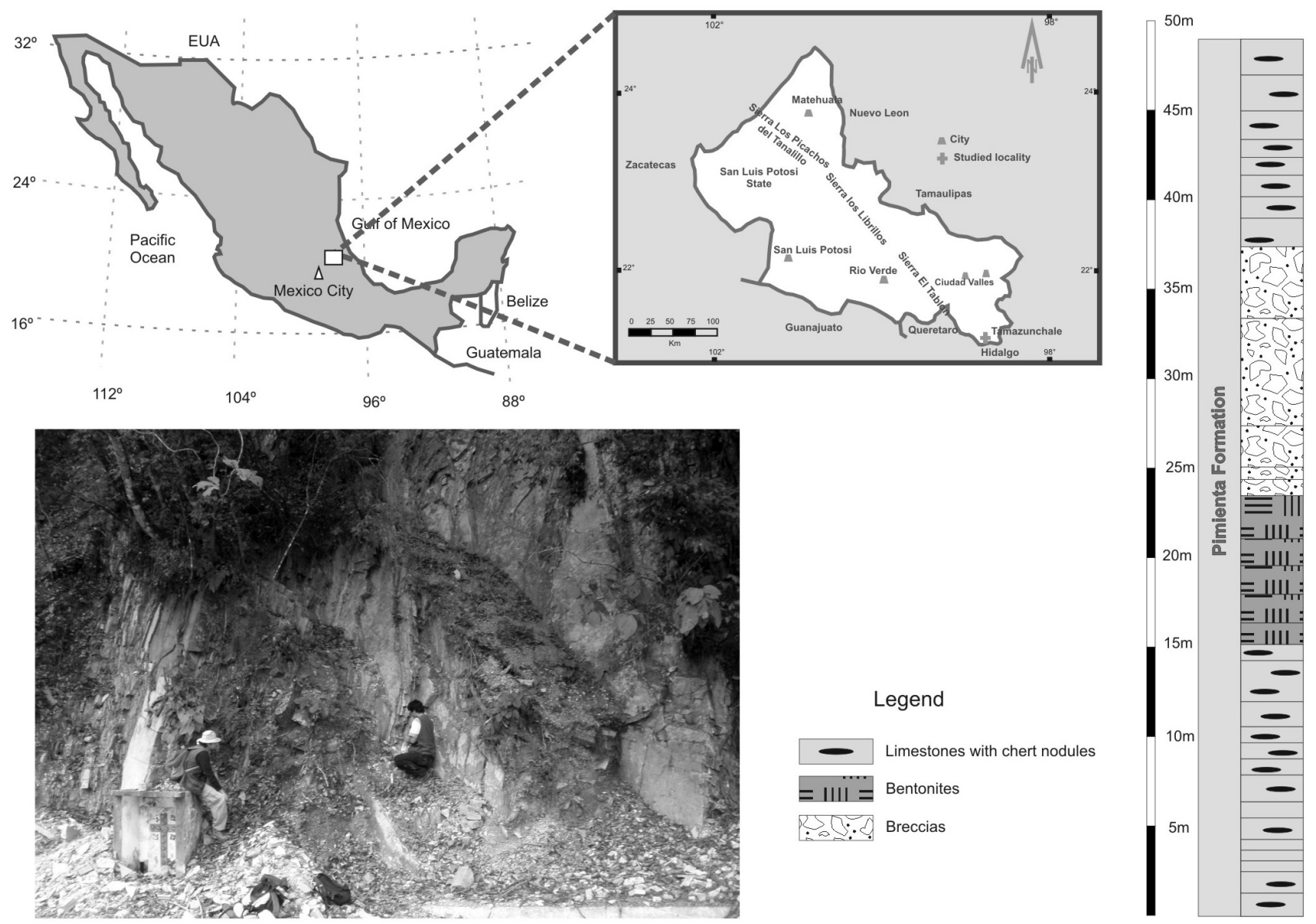

Figure 1. Location of the Tamazunchale section

\subsubsection{Crassicollaria Zone, Colomi Subzone. Samples: TMZ 11-19.1}

The subzone was defined by Pop (1994) by the FO of Crassicollaria colomi Doben. In the studied section Crassicollaria colomi Doben (Figure $3 \mathrm{~K}$ ) appears in sample TMZ 11 accompanied by Crassicollaria sp. (Figure 3 E), Crassicollaria parvula Remane (Figure 3 L), Calpionella alpina Lorenz (Figure 4 A), Chitinoidella boneti Doben (Figure 4 B), Praetintinnopsella andrusovi Borza (Figure 4 C, D), Tintinnopsella carpathica (Murgeanu and Filipescu) (Figure 4 E), Tintinnopsella subacuta Colom (Figure 4 F) and deformed tintinnopsellid loricas (Figure $4 \mathrm{G}$ ). A form with an unusual crassicollarian lorica with distinct double collar was noted (Figure $4 \mathrm{H}$ ), a feature interpreted as probably the product of bacteria induced mineralization.

An interval with the deformed calpionellids in the Crassicollaria Zone was documented by Borza (unpublished data) and Reháková (2000) and this coincided with the decline of crassicollarians and extinction of most Crassicollaria species near the Jurassic/Cretaceous boundary.

It is noteworthy, that Chitinoidella and Praetintinnopsella andrusovi Borza have never occurred so high in the
Crassicollaria Zone. Chitinoidellids often persist in the Praetintinnopsella Zone, but have never been documented in any normal succession in the Crassicollaria Zone. Similar chaotic distribution of stratigraphically important microfossils was documented in Remanei Subzone in France by Wimbledon et al. (2013). We can also interpret this as the result of sedimentary reworking. Nonetheless, it is an important finding because it indicates the presence of calpionellid biomarkers of the Chitinoidella Zone and the Praetintinnopsella Zones and, therefore, the certain communication of the Tampico-Misantla basin with the rest of the Tethys during the late Tithonian.

The finding of Tintinnopsella subacuta Colom in the Crassicollaria Zone is another unexpected result. This species is reported from Berriasian strata but has never been reported in the Tithonian. Additional studies are necessary to clarify the total range of this species in Mexican sections.

This subzone can be divided into two main parts according to microfacies.

The first one, TMZ 11-15, comprises wackestones to packstones dominated by radiolarians with scarce calpionellids.

The second one, TMZ 16-19.1, is composed of 


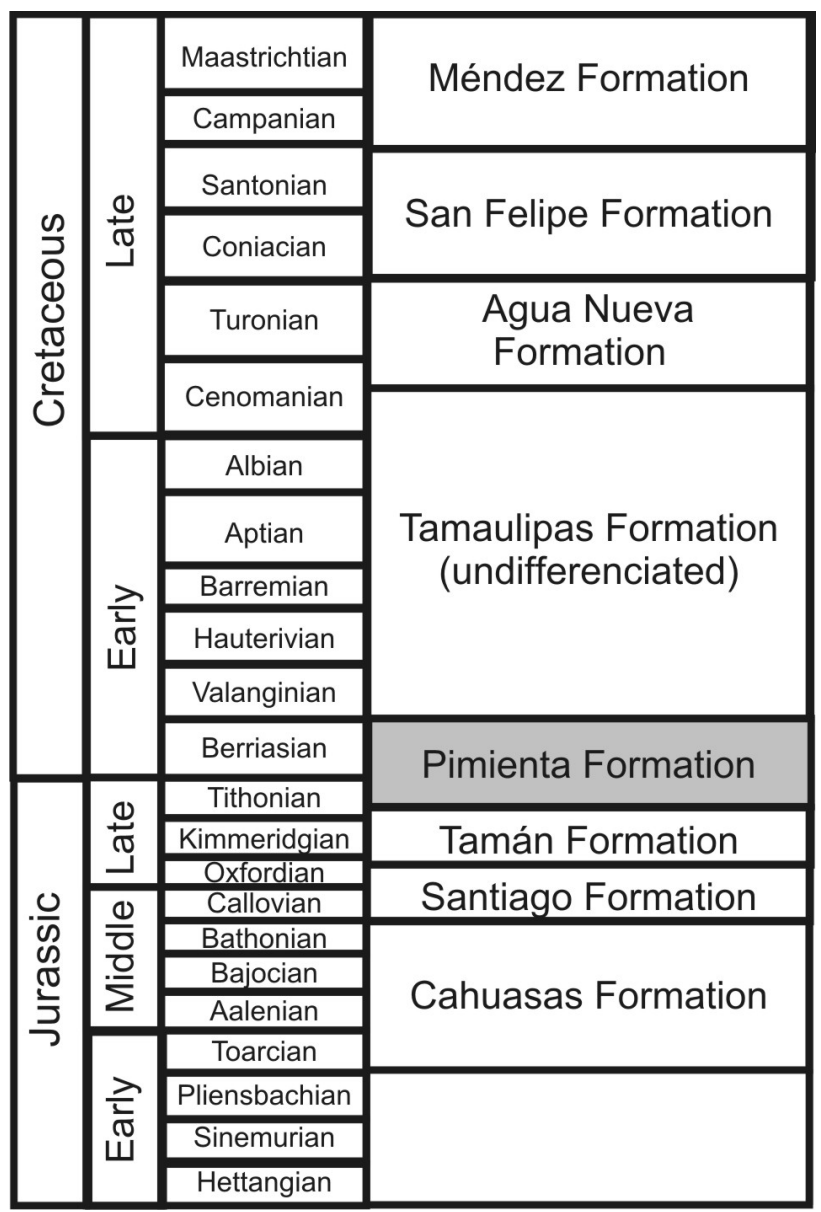

Figure 2. Jurassic and Cretaceous formations of the studied area. Studied interval is in gray.

bentonites and intercalations of radiolarian wackestonepackstone. The bentonites are green-gray in color and well stratified (Figure 4 I). Their tabular bed form and parallel stratification, and their assumed sedimentation in deep-water conditions, point to a free fall volcanic ash. In thin section it is possible to observe some altered volcanic glass, micas, quartz and plagioclases (Figure $4 \mathrm{~J}$ ).

\subsubsection{Erosional and breccias beds. Samples: TMZ 20-22}

An abrupt change in microfacies is seen in sample TMZ 20 . The bentonites and radiolarian wackestones-packstones are suddenly replaced by thick breccias of around twelve meters (Figure 5 A, B).

The breccias are either mud supported or subordinately clast supported; clasts differ in shape and size. In thin section, zones with sparitic matrix (Figure $5 \mathrm{C}, \mathrm{D}$ ) alternating with more micritic matrix can be observed.

Clasts are mainly made up of micrite grains, peloids, benthic foraminifers, algae fragments (Figure $5 \mathrm{E}$ ), mollusk debris and other shallow water derived bioclasts like fragments of the ulvophycean algae Lithocodium agregatum Elliott (Figure $5 \mathrm{~F}$ ).

\subsubsection{Calpionella Zone. Elliptica Subzone. Samples: TMZ 23-32}

The Elliptica Subzone was defined by Catalano and Ligouri (1971) by the FO of Calpionella elliptica Cadish. In the studied section the calpionellid association was determined in the breccia matrix and is composed of Calpionella elliptica Cadish (Figure 6 A), Calpionella alpina Lorenz (Figure 6 B), Remaniella colomi Doben (Figure 6 C), Remaniella ferasini Catalano (Figure 6 D) and Tintinnopsella longa Colom (Figure 6 E) and frequent radiolarian (Figure 6 F). In the Mediterranean Tethys and central Europe the species Tintinnopsella longa appears usually in the uppermost part of the Elliptica Subzone. Therefore, Pop (1997) proposed the Longa Subzone as the last subzone of the Calpionella Zone. The biomarkers of the higher Calpionellopsis and Calpionellites zones have not been identified in the Tamazunchale section.

\subsection{U-Pb geochronology}

The analyzed tuff sample (TMZ 19) yielded colorless and amber-colored euhedral zircon grains ranging from 30 to $200 \mu \mathrm{m}$ in size. Scarce dark brown, metamict zircons were also observed but not considered for isotopic analysis. CL images show the predominance of concentric oscillatory and sector zoning that are typical of magmatic zircons (Connelly, 2001; Corfu et al., 2003). Th/U ratios are $>0.1$ for all analyzed grains, supporting a magmatic origin for these zircons (Rubatto, 2002). Given the small dimension of most grains and the recurrent apatite and opaque inclusions, only 11 grains gave ages that vary from 134.7 to $378.0 \mathrm{Ma}$ (Figure 7 A). Nine grains yielded concordant to slightly discordant ages that define $\mathrm{a}^{206} \mathrm{~Pb} /{ }^{238} \mathrm{U}$ weighted mean of $139.1 \pm 2.6$ Ma (Figure $7 \mathrm{~B}$ ). This age is interpreted as reflecting the time of emplacement of the analyzed felsic tuff. Two grains yielded discordant ages of 308.6 and $378.0 \mathrm{Ma}$ (Figure 7 A) that we interpret due to mixing with xenocrystic cores inherited from Paleozoic or older rocks assimilated during the Lower Cretaceous volcanic event.

\section{Discussion}

The distribution of calpionellids in the Tamazunchale section does not prove the zonal scheme that is known from many Tethyan sections (Figure 8). Also, the biological components present reflect different environmental conditions. While calpionellids (mainly crassicollarians) dominated in late Tithonian microfacies in the European and North African Tethyan regions, radiolarians reflecting upwelling and rich nutrient conditions, prevailed in the westernmost Tethyan areas.

In spite of the scarcity of calpionellids, more detailed sampling has made possible the establishment of a more complete division of the late Tihonian Crassicollaria Zone. 

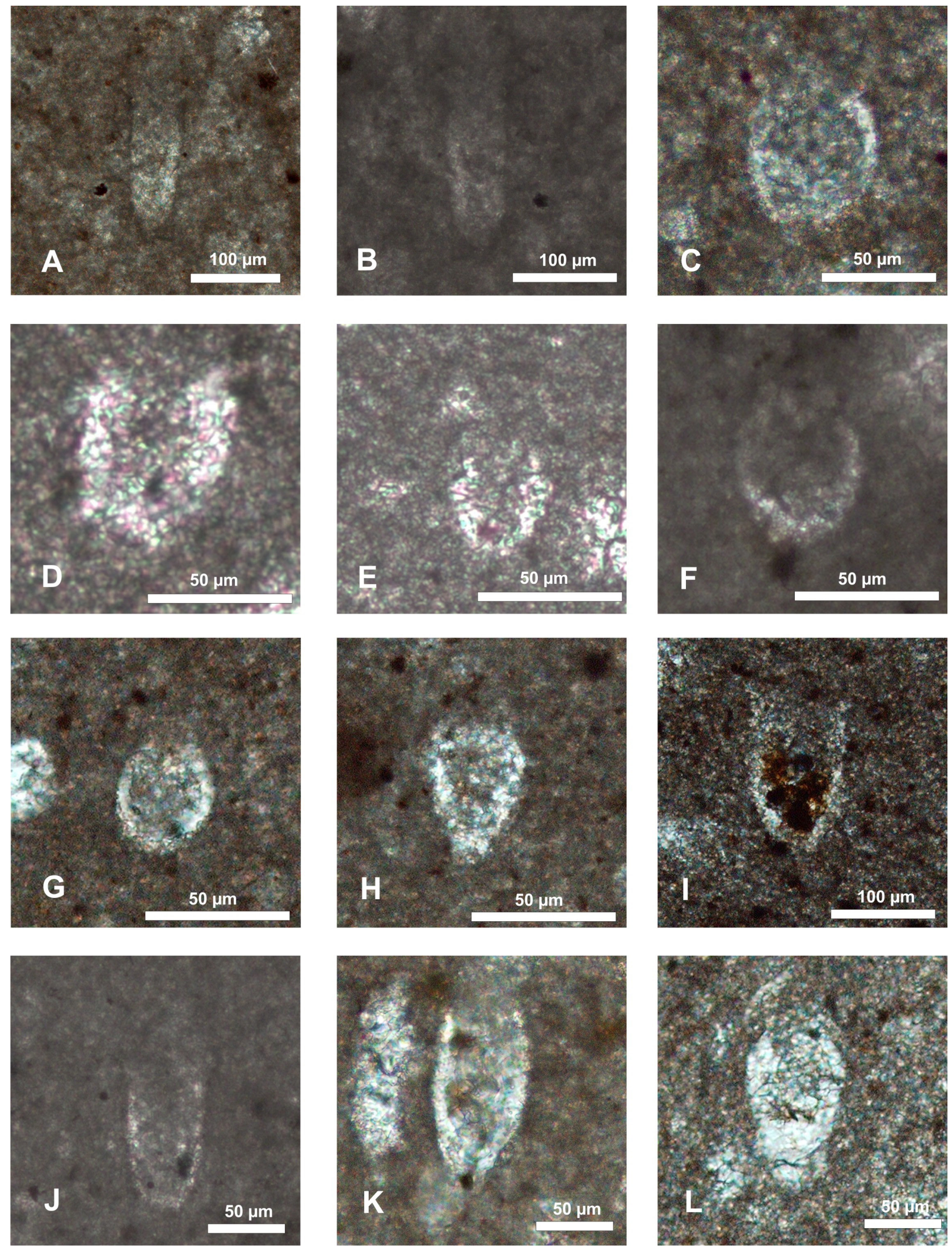

Figure 3. Calpionellids of the Crassicollaria Zone. A, B: Chitinoidella cf. elongata (Pop). Sample TMZ 2.0. C, D: Tintinnopsella remanei (Borza). Sample TMZ 2. E: Crassicollaria sp. Sample TMZ 2.1. F: Calpionella alpina Lorenz. Sample TMZ 3.2. G: Calpionella alpina Lorenz. Sample TMZ 10.0. H: Crassicollaria massutiniana Colom. Sample TMZ 8. I: Tintinnopsella carpathica (Murgeanu and Filipescu). Sample TMZ 8. J: Praetintinnopsella andrusovi Borza. Sample TMZ 9. K: Crassicollaria colomi Doben. Sample TMZ 11. L: Crassicollaria parvula Remane. Sample TMZ 11. 

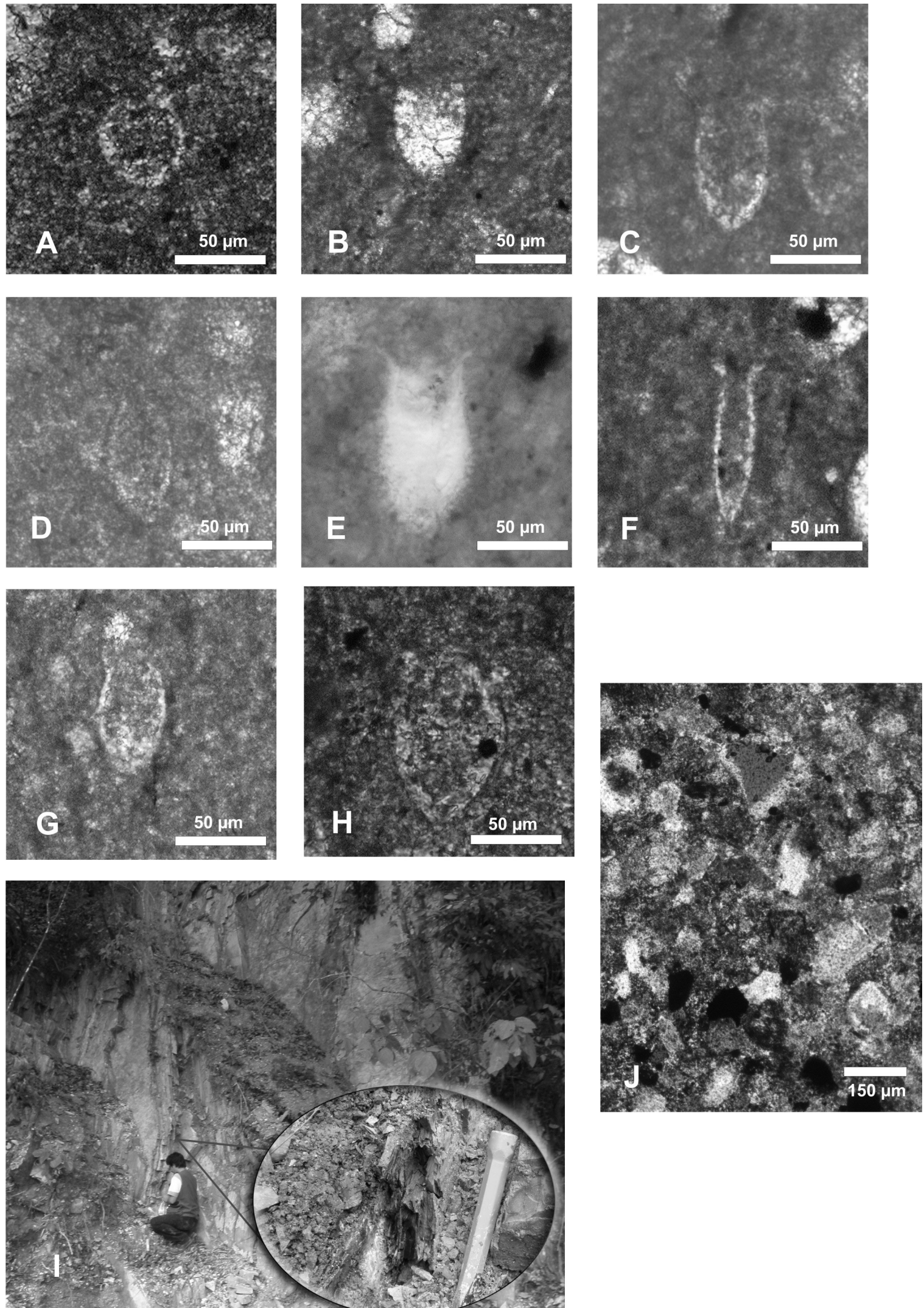

Figure 4: Calpionellids and facies of the Crassicollaria Zone. A: Calpionella alpina Lorenz. Sample TMZ 12. B: Chitinoidella boneti Doben. Sample TMZ 12. C, D: Praetintinnopsella andrusovi Borza. Sample TMZ 12. E: Tintinnopsella carpathica (Murgeanu and Filipescu). Sample TMZ 13.1. F: Tintinnopsella subacuta Colom. Sample TMZ 13. G: Deformed tintinnopsellid loricas. Sample TMZ 17. H: Unusual crassicollarian lorica with distinct double collar may be due to bacterial mineralization. I: Outcrop of the Tamazunchale section showing the bentonite layers. J: Bentonite in thin section. Some altered micas, volcanic glass, quartz and plagioclases. 
Thus, the zone can be divided into the same subzones (Remanei, Brevis and Colomi Subzones) as those described for Tethyan areas farther east. This fact indicates a constant arrival of calpionellids to Mexican regions through a permanent connection with the main part of Tethys.

The presence of Chitinoidella boneti Doben and Praetintinnopsella andrusovi Borza in the Brevis subzone is considered to be the result of reworking, but this type of mixing has never been reported at a stratigraphic level as high as the Brevis Subzone. This is interpreted as the result of an agitated water regime reworking sediments that persisted until the Colomi Subzone in this area.

The Crassicollaria Zone terminated with signs of active regional volcanism reflected by intervals with bentonites. The change in sea water temperature and high input of nutrients could have lead to large scale mortality of oligotrophic organisms (among them also calpionellids). Volcanic activity is reflected by deposition of bentonites
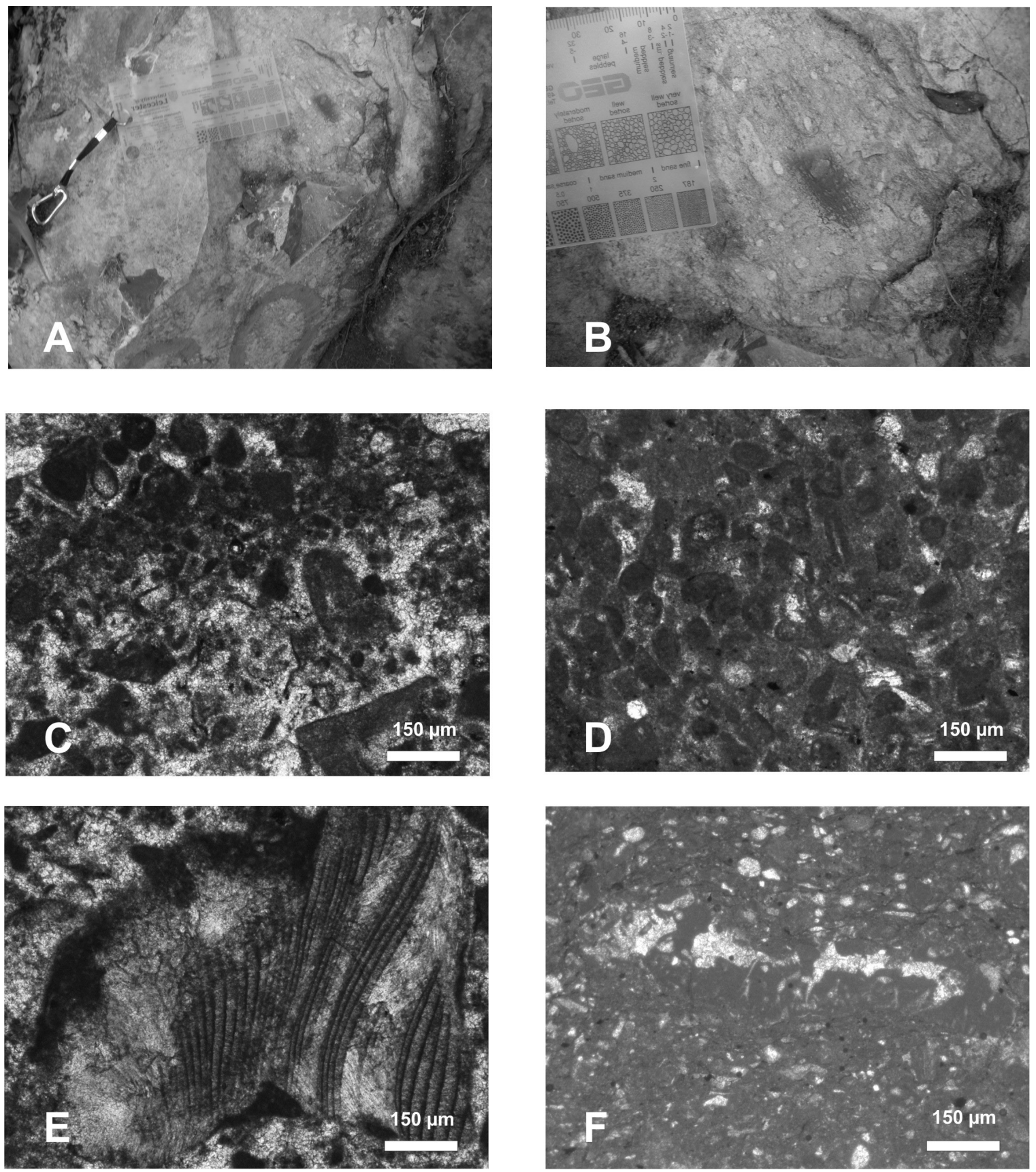

Figure 5: Main features of breccias beds in outcrop and in thin section. A, B: Features of the brecciated limestone in outcrop. Sample TMZ 20. C, D: Thin section view of sample TMZ 20. Breccias are mainly composed of peloids, micritic grains and fossil fragments. The matrix varies from sparitic to micritic in different areas. E: Frequent red algae fragments appear in the entire breccia interval. Sample TMZ 23. F: Ulvophycean algae Lithocodium agregatum Elliott. Sample TMZ 23. 
in which the last bed (TMZ 19) shows a geochronological age of $139.1 \pm 2.6 \mathrm{Ma}$. According to Gradstein et al., 2012 (International Stratigraphic Chart) this age corresponds to approximately to the Berriasian - Valanginian boundary.

The bentonites are covered by thick breccia beds also containing bioclasts derived from shallow water suggesting erosion that accompanied sea-level fall.

More or less coeval breccias beds have been identified in some Tethyan sections (Borza et al., 1980; Reháková, 2000; Benzaggagh, 2011; Eguiluz et al., 2012). In the western Carpathians Reháková (2000) and Michalík (2007) described a similar event as the "Nozdrovice Breccia".

In the lowermost samples from the breccia bed (Samples TMZ 20, 21, 22) it has not been possible to find any biostratigraphical marker. However, within the matrix of sample TMZ 23 calpionellids start to appear again. It is
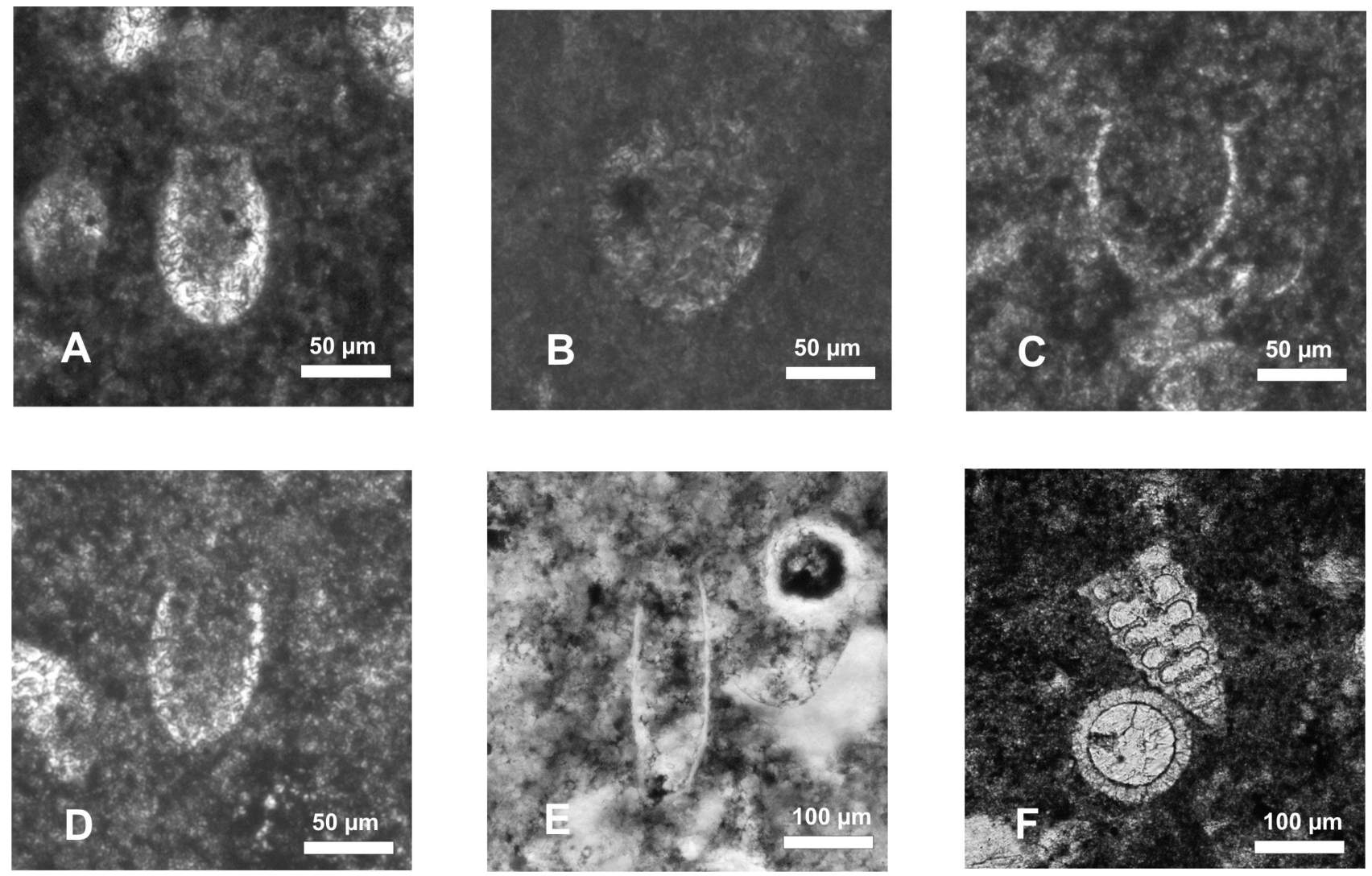

Figure 6. Microfossils of the Elliptica Subzone. A: Calpionella elliptica Cadish. Sample TMZ 24. B: Calpionella alpina Lorenz. Sample TMZ 24.2. C: Remaniella colomi Doben. Sample TMZ 30. D: Remaniella ferasini Catalano. Sample TMZ 28. E: Tintinnopsella longa Colom. Sample TMZ 31. F: Some well preserved radiolarian.
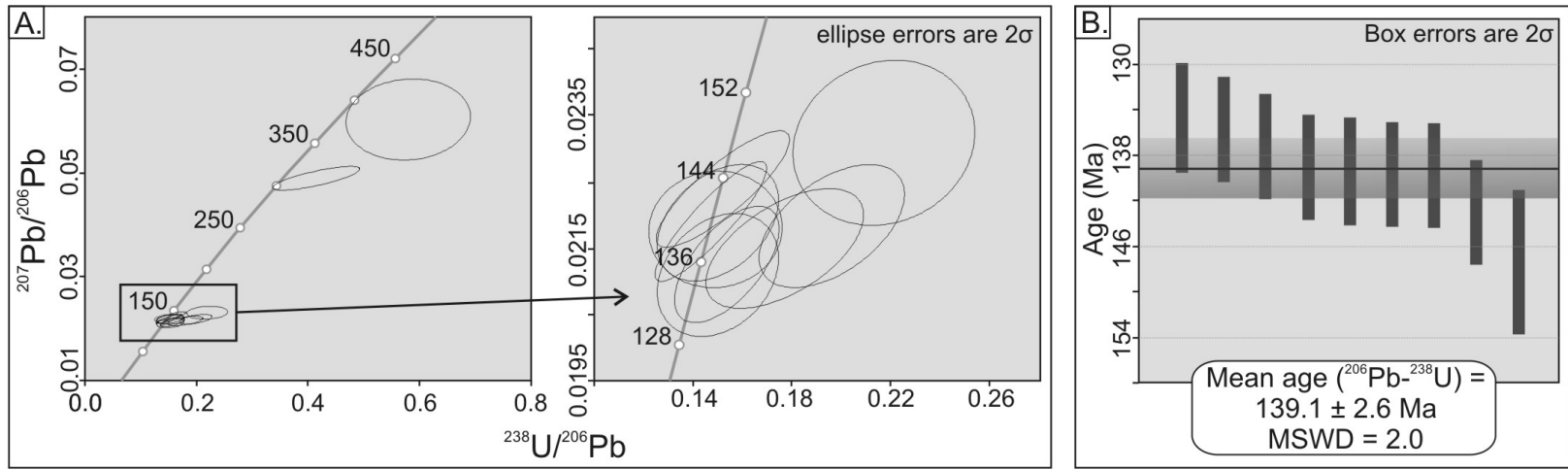

Figure 7. A: Tera-Wasserburg (1972) and B: weighted mean diagrams for the dated tuff sample TMZ 19. Plots were constructed using the ${ }^{206} \mathrm{~Pb} /{ }^{238} \mathrm{U}$ age for zircons younger than $1.0 \mathrm{Ga}$, whereas ${ }^{207} \mathrm{~Pb} /{ }^{206} \mathrm{~Pb}$ ages were preferred for grains older than $1.0 \mathrm{Ga}$. As a statistical rejection criterion, $10 \%$ normal and $5 \%$ reverse discordancy was chosen (Harris et al., 2004; Gehrels, 2011), and none of these zircons are included in the plots or discussion below. 


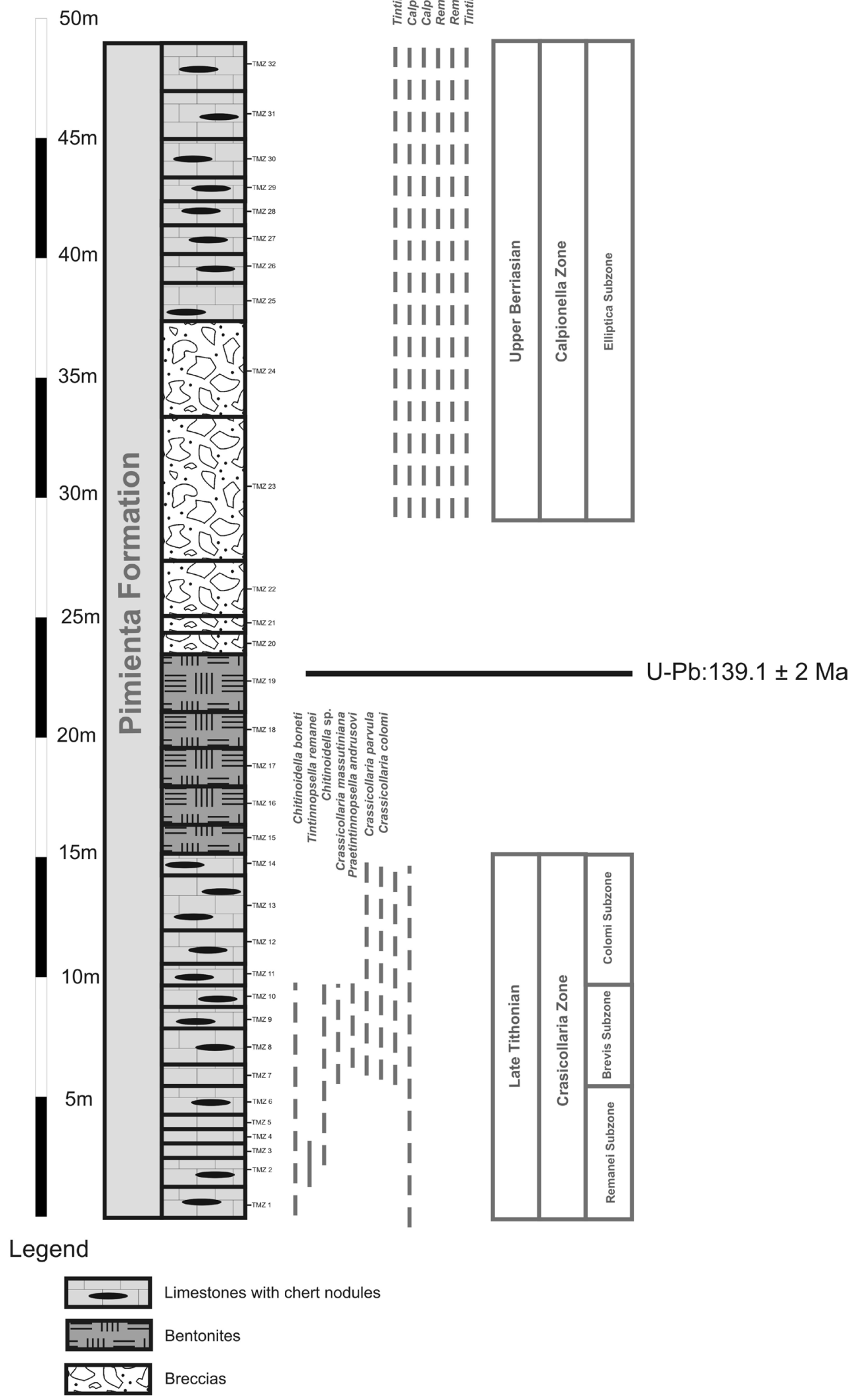

Figure 8. Calpionellid biozonation, bioevents and U-Pb age of the Tamazunchale section. 
possible to construct a calpionellid biozonation that starts in the Elliptica subzone but the Alpina and Ferasini Subzones are missing. A similar situation was reported in northern Mexico by Eguiluz et al. (2012).

The Elliptica Subzone was defined by several authors as middle Berriasian (see Figure 2). Nonetheless, the unexpected appearance of the Elliptica Subzone five meters above the last bentonite layer, dated at $139.1 \pm 2.6 \mathrm{Ma}$, suggests that the Elliptica subzone in Mexico is younger and at least late Berriasian. This new discovery points to different ranges for calpionellid biozones in Mexico, and offers new opportunities for the calibration of calpionellids bioevents in the main part of Tethys. More work is required to make regional correlations with calpionellids calibrated with U-Pb geochronology.

Upward, the section continues into the Elliptica Subzone but is then covered by soil and vegetation, which prevents more sampling for the moment.

\section{Conclusion}

The Tamazunchale section contains rocks dating from the late Tithonian to the late Berriasian (Crassicollaria Zone to Elliptica subzone). The Crassicollaria Zone was divided into the Remanei, Brevis and Colomi subzones. Microfossils corresponding to the Chitinoidella Zone and Praetintinnopsella point to a direct and continuous connection of this Mexican region with European Tethys during late Tithonian times.

The last bentonite bed dated at $139.1 \pm 2.6$ Ma suggests a different vertical distribution of calpionellids biozones in Mexico compared with the Mediterranean Tethys. Further work is necessary and desirable to clarify this point in different regions of Mexico.

\section{Acknowledgements}

This study was supported by grants PAPIIT IN109912, DGAPA, UNAM and CONACyT-SEP 177510, and also by projects of the Slovak Grant Agency: VEGA 2/0068/11 and VEGA 2/0042/12. The authors express their gratitude to Dr. María del Carmen Rosales Domínguez and Dr. William Wimbledon whose comments to the first draft of this manuscript served to enhance the quality of the work.

\section{References}

Adatte, T., Stinnesbeck, W., Hubberten, H.W., Remane, J., 1992, The Jurassic-Cretaceous boundary in Northeastern and Central Mexico. A multistratigraphical approach, in III Congreso geológico de España y VIII Congreso Latinoamericano de Geología, Salamanca, Actas 4, 23-29

Adatte, T., Stinnesbeck, W., Remane, J., 1994, The Jurassic-Cretaceous boundary in northeastern Mexico. Confrontation and correlation by microfacies, clay-mineral mineralogy, calpionellids and ammonites: Geobios, Memoire Special, 17, 37-56.

Adatte, T., Stinnesbeck, W., Remane, J., Hubberten, H.W., 1996, Paleogeographic setting of Center-East Mexico at the Jurassic/ Cretaceous boundary, correlation with NE-Mexico: Mitteilungen des Geologisch-Paläontologischen Instituts der Universität Hamburg, 77, 379-393.

Benzaggagh, M., 2011, Activités volcaniques sous-marines à la limite Jurassique-Crétacé dans le Rif externe (Maroc). Âge et relation avec la sédimentation et la paléogéographie du sillón rifain externe. C.R.: Geoscience, 343, 302-311.

Bondelos, A.J., 1956, Notas sobre la geología de la Sierra Madre en la sección Zimapán-Tamazunchale (libro guía), in XX Congreso Geológico Internacional, México, D.F: México, D.F., Excursiones A-14 y C-6, $323 \mathrm{p}$.

Bonet, F., 1956, Zonificación microfaunística de las calizas cretácicas del Este de México: Boletín de la Asociación Mexicana de Geólogos Petroleros, 8, 389-488.

Borza, K., Gašparíková, V., Michalík, J., Vašíček, Z., 1980, Upper JurassicLower Cretaceous sequence of the Krížna-nappe (Fatric) in the Strážovské vrchy Mts. (Western Carpathian): Geologický zborník - Geologica Carpathica, 31, 541-562.

Cantú-Chapa, A., 1967, El límite Jurásico-Cretácico en Mazatepec, Puebla. Estratigrafía del Jurásico de Mazatepec, Puebla (México): Instituto Mexicano de Petróleo, Sección Geología, Monografía, 1, 3-24.

Cantú-Chapa, A., 1971, La serie Huasteca (Jurásico Medio-Superior) del centro este de México: Revista del Instituto Mexicano del Petróleo, $3,17-40$.

Cantú-Chapa, A., 1989, Precisiones sobre el límite Jurásico-Cretácico en el subsuelo del Este de México: Revista de la Sociedad Mexicana de Paleontología, 2, 26-65.

Catalano, R., Ligouri, V., 1971, Facies à Calpionelle della Sicilia occidentale: Proceedings of the Second Plankton Conference, Roma $1970,1,167-210$.

Connelly, J.N., 2001, Degree of preservation of igneous zonation in zircon as a signpost for concordancy in $\mathrm{U} / \mathrm{Pb}$ geochronology: Chemical Geology, 172, 25-39.

Corfu, F., Hanchar, J.M., Hoskin, P.W.O., Kinny, P., 2003, Atlas of zircon textures: Reviews in Mineralogy and Geochemistry, 53, 469-500.

Eguiluz de Antuñano, S., Aranda-García, M., Marett, R., 2000, Tectónica de la Sierra Madre Oriental, México: Boletín de la Sociedad Geológica Mexicana, 53, 1-26.

Eguiluz de Antuñano, S., Olivares-Ramos, D., López-Martínez, R., 2012, Discordancia entre el Jurásico y Cretácico en Huizachal, Tamaulipas, México: su posible correlación con un límite de secuencia global: Revista Mexicana de Ciencias Geológicas, 29 (1), 87-102.

Gehrels, G., 2011, Detrital zircon U-Pb geochronology: Current methods and new opportunities, in Busby, C., Azor-Pérez, A., (eds.), Recent Advances in Tectonics of Sedimentary Basins: Chichester, UK, John Wiley \& Sons, 47-62, doi:10.1002/9781444347166.ch2.

Gradstein, F.M., Ogg, J.G., Hilgen, F.J., 2012, On the Geological Time Scale: Newsletters on Stratigraphy, 45(2), 171-188.

Harris, A., Allen, C., Bryan, S., Campbell, I., Holcombe, R., Palin, J., 2004, ELA-ICP-MS U-Pb zircon geochronology of regional volcanism hosting the Bajo de la Alumbrera $\mathrm{Cu}-\mathrm{Au}$ deposit: Implications for porphyry-related mineralization: Mineralium Deposita, 39, 46-67, doi:10.1007/s00126-003-0381-0.

Heim, A., 1940, The Front Ranges of Sierra Madre Oriental, Mexico, from Ciudad Victoria to Tamazunchale: Eclogae Geologicae Helvetiae, 33 (2), 313-360.

Lakova, I., 1993, Middle Tithonian to Berriasian praecalpionellid and calpionellid zonation of the Western Balkanides, Bulgaria: Geologica Balcanica, 23 (6), 3-24.

López-Martínez, R., Barragán, R., Reháková, D., 2013, The Jurassic/ Cretaceous boundary in the Apulco area by means of calpionellids and calcareous dinoflagellates: An alternative to the classical Mazatepec section in eastern Mexico: Journal of South American Earth Sciences, 47, 142-151. 
Ludwig, K.R., 2004, Isoplot/Ex, ver. 3, A geochronological toolkit for Microsoft Excel, Berkeley Geochronology Center, Publication 4, $70 \mathrm{p}$.

Lugo, E.J.E., 1975, Presence of Chitinoidella sp. (Tintinnidea, Codonellidae) in the Jurassic of the Southeastern of Mexico: Boletín de la Sociedad Mexicana de Geólogos Petroleros, 27 (10-12), 451-465.

Michalík, J., 2007, Rock record and microfacies indicators of the latest Triassic to mid-Cretaceous tensional development of the Zliechov Basin (central Western Carpathians): Geologica Carpathica, 58 (5), 443-453.

Morton, A.C., 1985, Heavy minerals in provenance studies, in Zuffa, G.G. (ed.), Provenance of Arenites: Reidel, Dordrecht, 249-277.

Pop, G., 1994, Calpionellid evolutive events and their use in biostratigraphy: Romanian Journal of Stratigraphy, 76, 7-24.

Pop, G., 1997, Tithonian to Hauterivian praecalpionellids and calpionellids: bioevents and biozones: Mineralia Slovaca, 29, 304-305.

Reháková, D., 2000, Calcareous dinoflagellates and calpionellid bioevents versus sea-level fluctuations recorded in the West-Carpathian (Late Jurassic/Early Cretaceous pelagic environments): Geologica Carpathica, 51 (4), 229-243.

Reháková, D., Michalík, J., 1997, Evolution and distribution of calpionellids - the most characteristic constituents of Lower Cretaceous Tethyan microplankton: Cretaceous Research, 18, 493-504.

Remane, J., 1986, Calpionellids and the Jurassic-Cretaceous boundary: Acta Geologica Hungarica, 29, 15-26.

Rubatto, D., 2002, Zircon trace element geochemistry: partitioning with garnet and the link between $\mathrm{U}-\mathrm{Pb}$ ages and metamorphism: Chemical Geology, 184, 123-138.

Salvador, A., 1991, Triassic-Jurassic, in Salvador, A. (ed.), The Gulf of Mexico Basin: The geology of North America, Boulder, Colorado, Geological Society of America, (J), 131-181.
Solari, L.A., Gómez-Tuena, A., Bernal, J.P., Pérez-Arvizu, O. Tanner, M., 2010, U-Pb zircon geochronology by an integrated LA-ICPMS microanalytical workstation: achievements in precision and accuracy: Geostandards and Geoanalytical Research, 34 (1), 5-18.

Stern, R.J., Dickinson W.R., 2010, The Gulf of Mexico is a Jurassic backarc basin: Geosphere, 6, 6, 739-754.

Stinnesbeck, W., Adatte, T., Remane, J., 1993, Mazatepec (Estado de Puebla, México)-Reevaluación de su valor como estratotipo del Límite Jurásico-Cretácico: Revista Española de Micropaleontología, 24, 63-79.

Sutter, M., 1990, Geología de la Hoja 14Q-e(5) Tamazunchale, Estados de Hidalgo, Querétaro y San Luis Potosí: México, D.F., Universidad Nacional Autónoma de México, Instituto de Geología, Carta Geológica de México, serie de 1:100000, 1 mapa con texto.

Tera, F., Wasserburg, G.J., 1972, U-Th-Pb systematics in three Apollo 14 basalts and the problem of initial $\mathrm{Pb}$ in lunar rocks: Earth and Planetary Science Letters, 14, 281-304.

Wimbledon, W.A.P., Reháková D., Pszczółkowski, A., Casellato, C.E., Halásová, E., Frau, C., Bulot, L.G., Grabowski, J., Sobień, K., Pruner, P., Schnabl, P., Čížková, K., 2013, An account of the bioand magnetostratigraphy of the upper Tithonian- lower Berriasian interval at Le Chouet, Drôme (SE France): Geologica Carpathica, 64 (6), 437-460.

Manuscript received: November 7, 2014.

Corrected manuscript received: February 10, 2015.

Manuscript accepted: February 15, 2015. 